DOI https://doi.org/10.18551/rjoas.2017-10.09

\title{
ECONOMIC AND LAW BASIS FOR FORMATION OF LOCAL BUDGET INCOMES: A STUDY ON THE EXAMPLE OF MUNICIPAL DISTRICTS AND RURAL SETTLEMENTS IN RUSSIA
}

\author{
Krasova E.V., Candidate of Economic Sciences \\ Vladivostok State University of Economics and Service, Vladivostok, Russia \\ E-mail: elena krasova@rambler.ru
}

\begin{abstract}
Formation of incomes of local budgets is the important direction of the Russian budgetary policy that is characterized by the constant overcoming of chronic shortage of funds. The main scientific and practical problem of the article is a number of difficulties in filling of local budgets. In Russia firstly this applies to the local budgets in far agricultural areas - municipal districts and rural settlements, where the economic potential is rather low. The purpose of the article is to disclose the economic and law basis for formation of local budget incomes (on the example of municipal districts and rural settlements). Methodological basis of the research are the theses of modern finance theory, fundamental principles of budget policy, the Russian concept of formation of local budgets. The article presents the most widespread types of municipalities in Russia - municipal districts and rural settlements as subjects of the budgetary system, considers the administrative and law foundations for formation of local budget incomes, studies the features of taxes' collection and fees in favor of local budgets.
\end{abstract}

\section{KEY WORDS}

Municipal districts, rural settlements, agricultural areas, local budget, local budget incomes, economic basis, law basis, budgetary system, federal taxes, local taxes.

In order to fulfill proper functions and provide comprehensive social and economic development of the territories, the governments of subjects in Russian Federation use the resources of regional and local budgets. In Russian Federation, in accordance with the principles of territorial organization, there are 85 subjects of RF, including 22 republics, 50 regions, 10 autonomous regions, 3 cities of federal significance - Moscow, St. Petersburg and Sevastopol, 22406 municipalities. A municipal formation is a city or rural settlement, or several settlements united by a common territory. In this territory there is a local government, also there are municipal property, a local budget and elected departments of local government (Dvoryadkina, Belikova and Aragilian, 2015).

Rural settlement is one or several villages, in which local government is realized directly by the population or through lawful elections («About General Principles...»). The number and the structure of municipalities in Russia are shown in table 1.

Table 1 - The number of settlements in Russia and Primorsky Region by types, 2016

\begin{tabular}{|l|c|c|c|c|}
\hline $\begin{array}{c}\text { Number of } \\
\text { municipalities }\end{array}$ & $\begin{array}{c}\text { In Russia as a } \\
\text { whole, units }\end{array}$ & $\begin{array}{c}\text { In Russia, } \\
\text { percentage share }\end{array}$ & $\begin{array}{c}\text { In Primorsky } \\
\text { Region, } \\
\text { units }\end{array}$ & $\begin{array}{c}\text { In Primorsky Region, } \\
\text { percentage share }\end{array}$ \\
\hline Total, including: & 22406 & 100,0 & 158 & 100,0 \\
\hline Municipal districts & 1788 & 8,0 & 22 & 13,9 \\
\hline City districts & 852 & 3,8 & 23 & 7,6 \\
\hline Urban settlements & 1592 & 7,1 & 101 & 63,6 \\
\hline Rural settlements & 18177 & 81,1 & & 63,9 \\
\hline
\end{tabular}

Source: Federal State Statistics Service of Russia.

As you can see, municipal districts and rural settlements are the most prevalent types of municipalities in Russia. Therefore, one of the most acute problems in formation of Russian budgets is to determine the role and functions of municipal and rural budgets in the 
budget system of Russian Federation. These budgets are called the local budgets (Afanasiev, Belenchuk and Krivogov, 2012). On the one hand, local budgets are the integral part of the country's financial system, and on the other hand, they are the financial basis of local government, which is not part of the system of state government in accordance with the Constitution of Russian Federation (Papelo and Goloshevskaya, 2014).

\section{RESULTS AND DISCUSSION}

Formation of incomes of local budgets has the same nature and is organized according to the same principles as the Federal budget. However, due to the specific nature of the Russian territorial organization, it has a number of features. In order to create a local financial system, to fill local budgets, and to protect the financial interests of municipal districts and rural settlements, the Council of municipal entities is formed in each subject of the Federation (Dementiev, 2016).

Each municipal district and rural settlement develops its Statute that is affirmed by the representative authority and represents the main legal document that defines the procedure for formation of local government, the economic and financial basis of the local government authorities, as well as guarantees for participation of the population in solving of local problems. The economic basis of local government includes: municipal property, local budgets, and property rights of municipalities. Incomes from privatization of municipal property are transferred to the local budgets. Local government must ensure the balance of local budgets and compliance with all requirements for the implementation of the budget process (Kayurov, 2013; Mogilev, 2013).

Speaking about the features of the budget process in municipal districts and rural settlements, it is necessary to distinguish issues that are managed by different types of municipalities. This differentiation of authorization is indicated by Russian Federal Law No. 131 «About General Principles of Organization of Local Government in Russian Federation». Local issues of the local settlements include: formation, approval, execution and control of the budget; establishment, modification and cancellation of local taxes and fees; possession, use and disposal of property; organization of electricity, heat, gas and water supply for the population; organization of collection and removal of domestic waste and garbage; statement of rules for improvement of territory of the settlement («About General Principles...»).

The Budget Code of Russian Federation clearly specifies the types of tax and non-tax incomes that make the basis for filling of local budgets, as well as the standards by which the amount of collected taxes is distributed among budgets of different levels.

Incomes for local budgets include revenues from local taxes and fees, revenues from federal and regional taxes and fees, non-tax payments, financial supports, as well as budget deficit financing. These funds are transferred to local budgets in accordance with the standards established by the Budget Code of Russian Federation («Budget Code...») (Figure 1).

It should be better to examine in detail the types, features and mechanism of tax collection in favor of local budgets.

At present time the Tax Code of Russian Federation (Article 15) provides for the following types of local taxes («Tax Code...»): Land tax; Tax on the property of individuals; Trade fee.

Organizations and individuals who have land plots on the right of full ownership, the right of perpetual use or the right to lifelong inheritance pay the Land tax. The object of taxation here are land plots located within a municipal district or rural settlement. The tax base for the Land tax is defined as the cadastral value of land plots in accordance with the land legislation of Russian Federation for the beginning of January each year. The Land tax rate is $0,3 \%$ for agricultural land, housing land and engineering infrastructure purchased for housing construction, land for personal farming (plant growing or cattle breeding), gardening, as well as for dachas and land for defense, safety and customs needs of the State («Tax Code...»; Yurchenko, 2010). 
The tax on the property of individuals is completely transferred to the budget of municipal districts. Individuals who own property rights for housing, garages, installations and others pay it.

Organizations and individual entrepreneurs who conduct entrepreneurial activities in different business spheres pay the Trade fee. Enterprises and entrepreneurs engaged in agricultural production are released from the payment of the Trade fee.

In addition to the local taxes, budget of municipal districts and rural settlements are filled by funds from federal and regional taxes that are distributed between the federal, regional and local budgets in accordance with the standards established by the Budget Code of Russian Federation: Tax on incomes of individuals; Agricultural tax; Tax on the alternative revenue; Government fees.

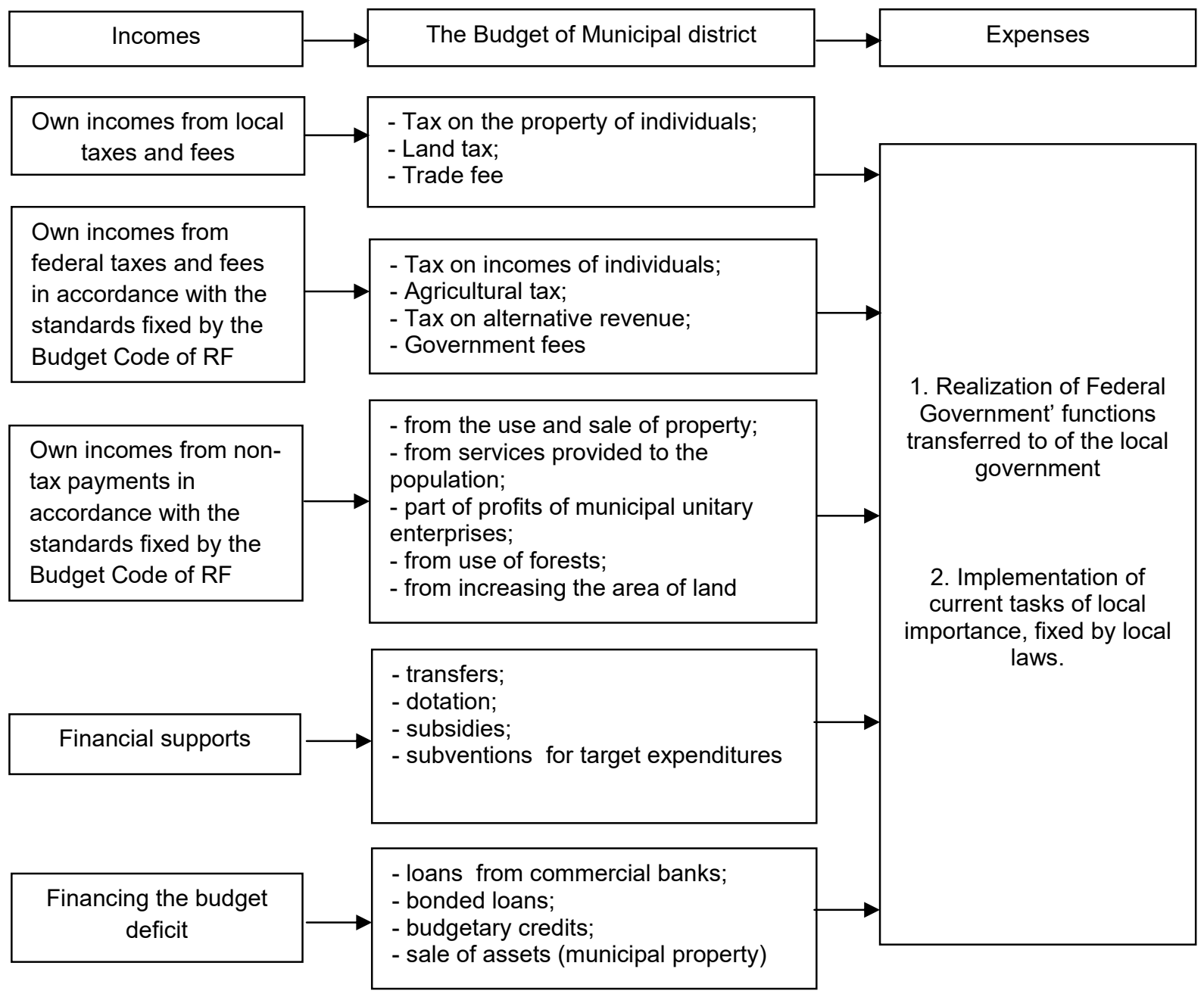

Figure 1 - The scheme of formation of incomes and realization of expenses of the local budget (on the example of municipal district)

In this paper, it should be interesting to study the Agricultural tax that is paid by organizations and individual entrepreneurs who produces agricultural products. Agricultural commodity producers include organizations and individual entrepreneurs that produce agricultural products, make the primary and subsequent processing of such products, and provided the $70 \%$ share of revenue from the sale of agricultural products. The object of taxation is income reduced by the amount of expenditure. The tax rate is $6 \%$ at present time. The mechanism of levying the Agricultural tax, as well as building a healthy local financial system, has particular importance for remote lands, including in the border areas (Astakhova and Aikhele, 2016). 
From the table 2 you can see that the further settlement from big cities and closer to uninhabited territories, the more the state leaves collected taxes in the local budget. This is explained by the objective difficulties that the economic entities and local budgets have in the process of economic activities: bad development of transport, poor socio-economic infrastructure, remoteness from urban and municipal centers, dependence of agricultural labor on weather and climate, terrain and other uncontrollable conditions (Korotaeva, 2012; Konvisarova and Uksumenko, 2016).

Table 2 - Tax incomes of municipal districts' budgets with indication of deduction rate according to the Budget Code of Russian Federation

\begin{tabular}{|l|l|}
\hline \multicolumn{1}{|c|}{ Types of Taxes } & Docal Taxes \\
\hline \multicolumn{1}{|c|}{ Federal Taxes } \\
\hline Land tax & $100 \%$ \\
\hline Tax on the property of individuals Rate for the Budgets of District \\
\hline \multicolumn{1}{|c|}{} \\
\hline $\begin{array}{l}\text { Tax on incomes of individuals levied on the territories } \\
\text { of urban settlements }\end{array}$ \\
\hline $\begin{array}{l}\text { Tax on incomes of individuals levied on the territories } \\
\text { of rural settlements }\end{array}$ \\
\hline Tax on incomes of individuals levied on far territories \\
\hline $\begin{array}{l}\text { Tax on the alternative revenue for some kinds of } \\
\text { economic activity }\end{array}$ & $100 \%$ \\
\hline $\begin{array}{l}\text { Agricultural tax levied on the territories of urban } \\
\text { settlements }\end{array}$ & $13 \%$ \\
\hline $\begin{array}{l}\text { Agricultural tax levied on the territories of rural } \\
\text { settlements }\end{array}$ & $100 \%$ \\
\hline Agricultural tax levied on far territories & $50 \%$ \\
\hline
\end{tabular}

In the Russian legislation there are special deduction rates for the budget of rural settlements (Table 3).

Table 3 - Tax incomes of rural settlement' budgets with indication of deduction rate according to the Budget Code of Russian Federation

\begin{tabular}{|c|c|}
\hline Types of Taxes & Deduction Rate for the Budgets of Settlement \\
\hline \multicolumn{2}{|c|}{ Local Taxes } \\
\hline Land tax & $100 \%$ \\
\hline Tax on the property of individuals & $100 \%$ \\
\hline Tax on incomes of individuals & Federal Taxes \\
\hline Agricultural tax & $2 \%$ \\
\hline
\end{tabular}

Non-tax incomes of municipal districts and rural settlements are formed on the base of non-tax payments. According to Article 62 of the Budget Code of RF, $100 \%$ of the following receipts remain in the local budget: income from the use of property; income from the sale of property; income from the provision of services; part of the profits of municipal unitary enterprises after payment of taxes; payment for use of forests; payment for increase of the area of land plots in private ownership, etc.

For budgets of municipal districts, urban and rural settlements, the standards of deduction rates for above types of non-tax incomes are at least $50 \%$ («Budget Code...»).

\section{CONCLUSION}

Thus, municipal districts and rural settlements implement the local government management for the benefit of the population, independently form and fill in the local financial system, realized through the local budget. We can say that the local budget is a financial basis for the implementation by local government of their functions and powers. The main sources of income of local budgets are taxes: land tax, tax on the property of individuals, tax on incomes of individuals, agricultural tax. The Budget Code of Russian Federation clearly 
indicates the order how the incomes of the local budget can be formed. Russian budget legislation provides the distribution of collected federal taxes in favor of local budgets. Special regulations are used for this.

\section{REFERENCES}

1. Dvoryadkina E.B., Belikova O.A., Aragilian I.V. (2015). Budgets of rural areas in the structure of regional fiscal and budgetary subsystems // Agrarian Bulletin of the Urals. No. 3 (133). P. 48-53.

2. Russian Federal Law «About General Principles of Organization of Local Government in Russian Federation». October 6, 2003, No. 131 (last version) [Electronic resource] // Official site of company "ConsultantPlus». URL: http://www.consultant.ru/document/ cons_doc_LAW_44571.

3. Formation of local government in Russian Federation for January 1, 2016 [Electronic resource] I/ Site of the Federal Service of State Statistics. URL: http://www.gks.ru/wps/wcm/connect/rosstat_main/rosstat/ru/statistics/publications/

4. Afanasiev M.P., Belenchuk M.P., Krivogov I.V. (2012). Budget and budget system: the textbook. Moscow: Publ. house YURAYT. 490 p.

5. Papelo V.N., Goloshevskaya A.N. (2014). Budgetary system of the Russian Federation: the textbook. Novosibirsk. 224 p.

6. Dementiev D.V. (2016). Budgetary system of Russian Federation: the textbook. Moscow: Publ. house Knorus. 332 p.

7. Kayurov E.A. (2013). Some aspects of increasing the effectiveness of system of forming the incomes for local budgets in Russia // Actual Problems of Russian Law. No. 9. pp. $1115-1122$.

8. Mogilev S.V. (2013). Analysis of socio-economic factors of local budget revenues // Finance and Credit. No. 47 (575). P. 58-65.

9. Budget Code of Russian Federation. Federal Law No. 145-FZ, July 31, 1998 (last version) [Electronic resource] // Official site of company «ConsultantPlus». URL: http://www.consultant.ru/document/Cons_doc_law_19702.

10. Tax Code of Russian Federation. Federal Law No. 146-FZ, July 31, 1998 (last version) [Electronic resource] // Official site of company "ConsultantPlus». URL: http://www.consultant.ru/document/cons_doc_LAW_19671.

11. Yurchenko T.V. (2010). Revenues of the buidgets of rural settlements as a factor of development of rural areas // Strategy for Sustainable Development of Russian Regions. No. 4. P. 91-96.

12. Astakhova E.V., Aikhele D.V. (2016). Features of international business in the border areas // Azimuth of Scientific Research: Economics and Management. Vol. 5. No.3(16). P. 14-17.

13. Korotaeva E.A. (2012). Problems of economic independence of local budgets in rural settlements // Bulletin of the Udmurt University. Series Economics and Law. No. 2-2. pp. $150-154$.

14. Konvisarova E.V., Uksumenko A.A. (2016). Problems of Financing Road Economy in the Context of Russian National Security // National Security / Nota Bene. No. 2. P. 276-285. 